脳血管障害患者の脳内神経活動に振動刺激が及ぼす影響

\title{
Effect of kinesthetic illusion elicited by tendon vibration on stroke patients
}

\author{
兒玉 隆之 ${ }^{1)}$ 大杉 紘徳 ${ }^{1)}$ 三谷 良輔 ${ }^{2)}$ 辻 湖保 ${ }^{2)}$ 森田喜一郎 ${ }^{3)}$

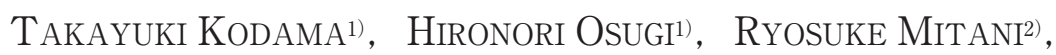 \\ Mizuho Tuji2), KiICHIRO MORITA ${ }^{3)}$
}

要旨: 本研究は, 脳血管障害患者に対する振動刺激によって, 脳内に惹起される運動錯覚 が脳神経活動へ及ぼす影響を, 神経生理学的指標として脑波 $\mu$ 波を eLORETA 解析によ り検討した。対象は感覚障害や認知機能障害のない運動障害を呈する脳血管障害患者10名 (患者群) であった。方法は, 安静時, 振動刺激時それぞれの条件下にて脳波 $\mu$ 波を計 測し，それぞれの脳神経活動を eLORETA 解析により比較検討した。結果，安静時は感 覚運動領野, 補足運動野における $\mu$ 波の発現を認めた。振動刺激時においては, 感覚運 動領野の有意な $\mu$ 波の発現は認めなかった。以上より, 運動障害をもつ脳血管障害患者 に扔いても，振動刺激がもたらす運動錯覚が感覚運動領野の神経活動性を高めることを示 唆した。

キーワード：振動刺激，運動錯覚，脳血管障害患者，LORETA

\begin{abstract}
The aim of this study was to examine the influence of vibratory stimulationinduced kinesthetic illusion on brain function with hemiparetic stroke patients by using EEG analysis. Ten stroke patients were studied. The subjects did not exhibit motor and sensory paralysis. Brain waves were measured in the resting condition and in the presence of vibratory stimulation. As a neurophysiological index to evaluate brain function, the $\mu$-rhythm, which is present mainly in the kinesthetic cortex and is attenuated by movement or motor images, was used. Calculated data were compared using analyses of Source Localization by the eLORETA. The results showed that, in the resting condition, the kinesthetic cortical $\mu$-rhythm appeared in the sensorimotor cortex and supplementary motor cortex. In the vibratory stimulation condition, no $\mu$-rhythm appeared in the sensorimotor cortex, These findings suggested that kinesthetic illusion increases the neural activities of the sensorimotor cortex.
\end{abstract}

Key words: vibratory stimulation, kinesthetic illusion, stroke patient, LORETA

\footnotetext{
受付日：2014年 1 月22日, 採択日：2014年 2 月20日

1) 京都橘大学健康科学部理学療法学科

干607-8175 京都府京都市山科区大宅山田町34

TEL : 075-574-4312 FAX : 075-574-4122

Email:kodama-t@tachibana-u.ac.jp

Department of Physical Therapy, Faculty of Health Sciences, Kyoto Tachibana University

2) 医療法人稲門会アビィロードやましな

Abbey Road Yamashina, Medical Corporation Toumonkai

3) 久留米大学高次脳疾患研究所

Cognitive and Molecular Research Institute of Brain Diseases and Kurume University, School of Medicine
} 


\section{I 、はじめに}

近年，ニューロリハビリテーションにおいて，運動 錯覚 ${ }^{1)}$ が脳血管障害患者に対するリハビリテーション に応用されている。運動錯覚とは, 実際の随意運動を 行わずとも四肢が動いたかのように創出される脳内錯 覚 ${ }^{1)}$ である。脳内の感覚運動情報により惹起される運 動錯覚は，感覚野や運動野を包括した感覚運動領野の 興奮を意味し，その神経活動を運動制御や習熟に応用 することは有効补とされている。

脳血管障害患者の運動障害に対しても，運動錯覚を 用いた治療効果に関する報告が多くなされている。中 でも, 運動錯覚を惹起させるために鏡を使用した治療 ${ }^{3}$ が多く報告されており, Altschulerら ${ }^{4)}$ は, 鏡を使用 した治療を脳血管障害患者の運動障害の治療に利用し た結果，発症後 6 ケ月後以上経過した慢性期の脳血管 障害患者においても運動機能の回復を認めたことを報 告している。また, Dohle ら ${ }^{5)}$ は, 脳血管障害後の重 症麻痺患者に対する鏡を使用した治療効果を検討して おり, 介入後手指の運動機能が向上したことを明らか にしている。しかしながら，運動錯覚を惹起させる際， 視覚的情報に対して能動的に情報処理を行うような介 入課題では, 認知機能, 視覚情報処理機能や健側肢の 運動機能など様々な脳機能のレベルが, 課題達成, つ まり運動錯覚の完成度に影響を及ぼすことが予測され る。そのため, 課題に用いる刺激自体はできるだけ簡 便かつ受動的なものであることが望ましいと考えられ る。

そこで我々は，運動錯覚を惹起させる方法として振 動刺激 ${ }^{6-8)}$ を用いた介入に着目した。これまで，運動錯 覚が脳機能へ及ぼす影響に関する研究では, $\mathrm{fMRI}^{8)}$ $\mathrm{MEG}^{9)}$ などを用いて検討した脳機能イメージング研究 がみられ, 関連する神経活動領域として, 一次感覚野, 感覚連合野, 補足運動野, 運動野, 角回の関連が報告 されている。しかしこれらの領域は，運動錯覚完成時 の神経活動を反映したものであり，運動錯覚生成過程 を反映したものではない。運動錯覚には, その錯覚さ れる運動に先立って感覚を予測し, 過去の感覚運動経 験を運動イメージとしてシミュレートしておくことが

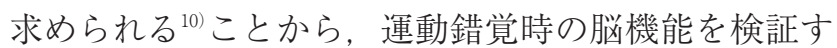
る上では，運動錯覚が惹起される前に脳内で運動イ メージが開始された時点からの, より詳細な時間的空 間的解析が求められる。

これらを捉えるための神経生理学的指標として, 脳 波 $\mathrm{Mu}$ リズム ${ }^{11)}$ (以下： $\mu$ 波）が有用であると考えら
れる。 $\mu$ 波は10 $13 \mathrm{~Hz}^{12)}$ 付近の High $\alpha$ 帯域成分であ り，実際の運動のみならず運動イメージなどによって も減衰する ${ }^{13-15)}$ ため, 生成過程を含めた運動錯覚時の 脳神経活動を捉えることが可能となる。これまで，健 常者における運動錯覚と $\mu$ 波の関連性は報告されて いる ${ }^{16)}$ が，脳血管障害患者における振動刺激の影響を $\mu$ 波により検討した報告は我々の知る限りない。以上 より, 本研究の目的は, 運動錯覚が脳血管障害患者の 脳内神経活動へどのような影響を及ぼすかについて， $\mu$ 波を脳機能イメージング解析により検討することで ある。

\section{II. 対象と方法 \\ 1. 対 象}

対象は, 脳血管障害患者 10 名 (男性 5 名, 女性 5 名) (平均年齢 $61.3 \pm 3.8$ 歳) (以下：患者群) を対象とし た。患者群においてはいずれも認知機能障害および出 血, 梗塞による視床の後内 - 外腹側核, 表在感覚およ び深部感覚情報伝導路に障害がなく感覚障害のないこ とを確認した。患者群の属性を表 1 に示す。対象者に は, ヘルシンキ宣言に則り本研究の主旨と内容, およ び個人情報の漏洩に注意することについて紙面および 口頭にて説明し，理解を得た上で書面への署名にて同 意を得た。健常群の利き手は, Edinburgh Inventory ${ }^{17)}$

表 1 患者群の属性

\begin{tabular}{|c|c|}
\hline 項 目 & \\
\hline 年齢（歳） & $61.3 \pm 3.8(56-68)$ \\
\hline 男女比 & $1: 1(\mathrm{n}=10)$ \\
\hline \multicolumn{2}{|l|}{ 診断名 } \\
\hline \multicolumn{2}{|l|}{ ラクナ梗塞 } \\
\hline - 視床 & 5 \\
\hline －被殼 & 2 \\
\hline \multicolumn{2}{|l|}{ 脳出血 } \\
\hline - 視床 & 1 \\
\hline - 被殼 & 2 \\
\hline \multicolumn{2}{|l|}{ 麻痺側 } \\
\hline 右麻痺 & 10 \\
\hline 左麻痺 & 0 \\
\hline \multicolumn{2}{|l|}{ 利き手側 } \\
\hline 右利き & 10 \\
\hline 左利き & 0 \\
\hline 発症からの期間（月） & $11.6 \pm 7.5$ \\
\hline UE-FMA & $20.1 \pm 4.1$ \\
\hline MMSE & $27.1 \pm 1.3$ \\
\hline
\end{tabular}

UE-FMA, Fugl-Meyer Assessment（上肢） MMSE, Mini-Mental State Examination 
にて評価し，全例が右利きであることを確認した。

\section{2. 方 法}

\section{1 ) 課題条件}

対象者に対して，背もたれ角度調節付きの椅子に左 上肢前腕（非測定側上肢）を肘置きに置いた状態でリ クライニング座位姿勢をとらせ, リラックスのできる 安静状態を設定した。始めに，コントロール条件とし ての安静状態 (以下: 安静) と課題条件として振動刺 激を加えた時（以下：振動刺激）の二つの条件下で脳 波計測を実施することを説明した。振動刺激により運 動錯覚を生じさせる目的運動は右肘関節伸展としたた め, 刺激部位は右上腕二頭筋腱とした。刺激は皮膚上 から行うため, 筋紡錘のみでなく皮虐刺激受容器も刺 激する。感覚運動情報により变化する $\mu$ 波は, 皮虐 刺激から受容した感覚情報によっても影響を受ける ため, 両条件における統制条件として, 振動刺激では 上腕二頭筋の筋収縮による肘関節屈曲を防ぐこと ${ }^{18)}$ 想定し, 計測者は上肢が体幹に触れないよう前腕を把 持 ${ }^{19}$ し，ハンディマッサージャー（スライブ株式会社 製，THRIVE MD-01）を右上腕二頭筋腱上へセッティ ングした。安静では振動刺激を加えず脳波計測を行い, 振動刺激は周波数 $91.7 \mathrm{~Hz}^{1,8,20}$ にて振動を加え $\mu$ 波を 計測した。また，振動刺激中実際には動いていない上 肢の視覚情報は運動錯覚を軽減させる ${ }^{6}$ ため閉眼させ た。振動刺激は合計二回実施し, 計測した二回分の脳 波デー夕の平均值を求め被験者毎のデータとした。一 回目と二回目の間には10分間の休息をとった。

2 ) 脳波計測および脳機能イメージング解析

脳波記録は日本光電社製 Neurofax を使用した。計 測部位は，国際10-20法に基づき，両耳架を基準電極 とした $\mathrm{F}_{3}, \mathrm{~F}_{4}, \mathrm{~F}_{7}, \mathrm{~F}_{8}, \mathrm{Fz}, \mathrm{C}_{3}, \mathrm{C}_{4}, \mathrm{Cz}, \mathrm{P}_{3}, \mathrm{P}_{4}, \mathrm{Pz}$, $\mathrm{O}_{1}, \mathrm{O}_{2}, \mathrm{O} z, \mathrm{~T}_{3}, \mathrm{~T}_{4}, \mathrm{~T}_{5}, \mathrm{~T}_{6}$ の18部位より導出し, バンドパスフィルターは $0.5 \sim 60 \mathrm{~Hz}$, サンプリング周 波数は $1000 \mathrm{~Hz}$ にて計測した。計測時間は, 安静を60 秒間計測し, 振動刺激は 1 回を60秒間8)とした。

イメージング解析として，まず条件毎に得られた データから30エポック（1エポックは2秒間）を抽出 した。次に脳波計測後周波数解析にて算出された $\mu$ 波周波数帯域 $(10 \sim 13 \mathrm{~Hz})$ のデー夕を用いて, 脳内神 経活動の三次元画像表示法である exact Low Resolution Brain Electromagnetic Tomography（以下：eLORETA）解析 ${ }^{21.22}$ による脳内空間的解析を行った。そ の結果, 条件毎の脳内神経活動領域が各ボクセル上で
の神経活動值として算出され, Brodmann area(以下： BA）や MNI 座標 ${ }^{23}$ として特定される。それら条件毎 に得られた被験者分のデータに対して, eLORETA 解析プログラム内にある eLORETA Averagerにより 加算平均化を行うことで, 両群における安静および振 動刺激の global field power (GFP) 值 ${ }^{21}$ として神経活 動領域が算出されるため, それらについて検証した。 さらに, 各条件における両群の脳内神経活動の比較に は, 同解析プログラム内の statistics eLORETA $\mathrm{SnPM}^{24)}$ を用い比較検討した。eLORETA 解析では有 意差（統計的有意水準は $5 \%$ ）を認めた神経活動領域 には着色がなされ算出描画される。 $\mu$ 波は運動感覚皮 質上 ${ }^{13)}$, その他の前頭葉 ${ }^{25)}$ や後頭葉 ${ }^{26)}$ に発現した場合 は $\alpha$ 波など, 同じ周波数帯域でも発生領域により波形 成分や名称が異なるため区別して用いた。

\section{III. 結 果}

解析に先がけ，振動刺激に「肘関節にどのような感 覚が生じたか」の口頭による質問に対して，「肘がずっ と伸びつづけていた感じがした」，「肘が勝手に反対方 向へ動きつづけた感じ」など対象者10名全員が回答し， 運動錯覚が惹起されたことを確認した。

\section{1. $\mu$ 波帯域の脳内神経活動}

安静における $\mu$ 波周波数带域での脳内神経活動性 を算出した結果, 運動野BA 4 抢よび感覚野BA 3 , 1，2 2含む感覚運動領野，補足運動野BA 6 および $\alpha$ 波として前頭前野および後頭葉の広範な領域に, 他 の大脳皮質領域と比較し有意に高い神経活動を認めた

(図1-a)。振動刺激に打ける $\mu$ 波周波数帯域での脳 内神経活動性は，他の大脳皮質領域に比較し後頭葉の 有意に高い神経活動を認めたが, 感覚運動領野の有意 な神経活動は認めなかった（図1-b)。振動刺激と安 静における $\mu$ 波帯域の脳内神経活動を比較した結果, 安静に比較し振動刺激の方が後頭葉および前頭前野の 有意な増加を認めたが, 感覚運動領野および補足運動 野BA 6 は安静が有意に増加した（図1-c）。

\section{考 察}

本研究は，振動刺激により惹起される運動錯覚が, 脳血管障害患者の脳内神経活動へ及ぼす影響について, 神経生理学的指標である脳波 $\mu$ 波を用いた脳機能イ メージング解析により検討した。

安静に扔ける $\mu$ 波周波数帯域での脳内神経活動性 

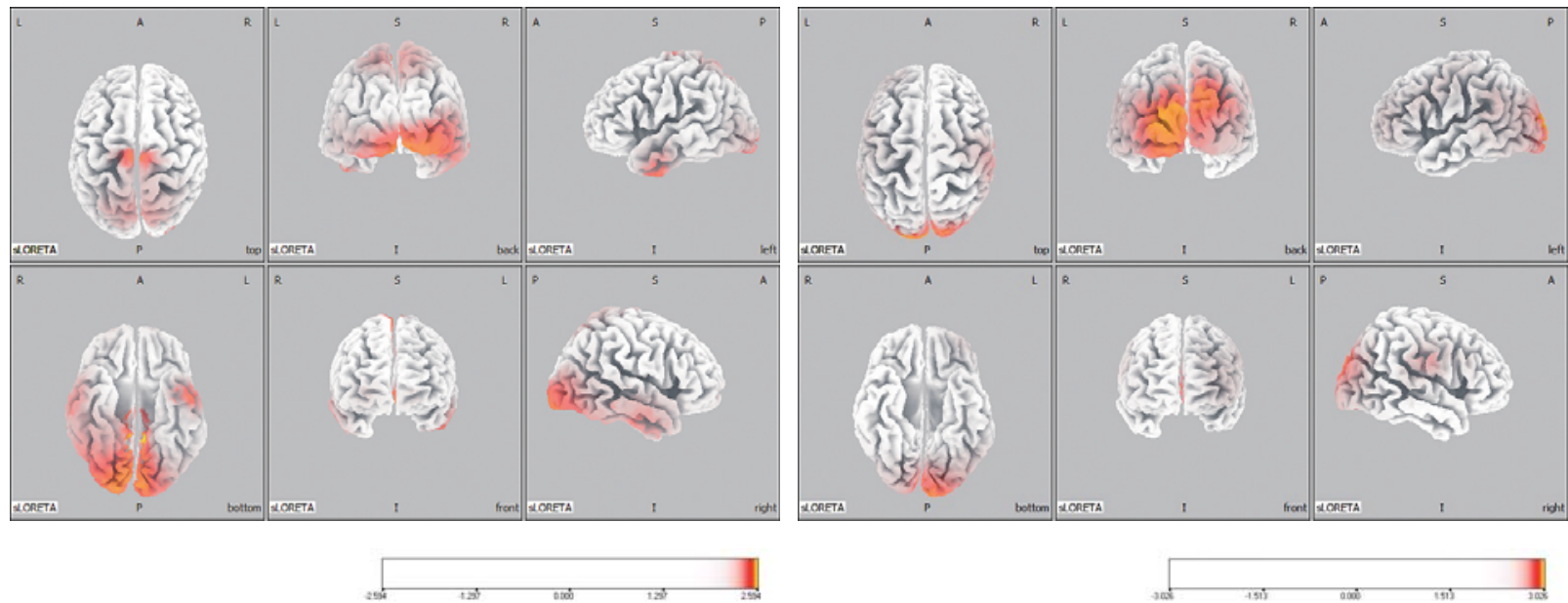

a b

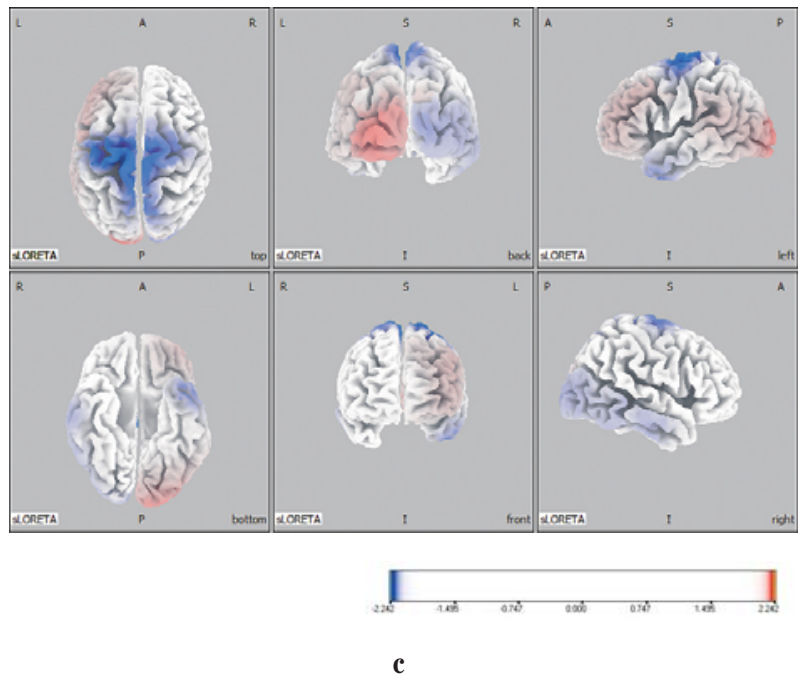

図 $1 \mu$ 波周波数帯域の脳神経活動

$\mathrm{a}$ : 安静の $\mu$ 波周波数带域の脳神経活動

黄色および赤色で示された領域は $\mu$ 波， $\alpha$ 波が有意に増大した脳領域を示す。

$\mathrm{b}$ ：振動刺激の $\mu$ 波周波数帯域の脳神経活動

黄色および赤色で示された領域は $\mu$ 波， $\alpha$ 波が有意に増大した脳領域を示す。

$\mathrm{c}$ ：振動刺激と安静の脳神経活動の比較

黄色および赤色で示された領域は安静に比較し振動刺激の $\mu$ 波， $\alpha$ 波が有意に増大した部位を示波が有意に 増大した部位を示し, 水色㧍よび青色で示された領域は振動刺激に比較し安静の $\mu$ 波, $\alpha$ 波が有意に増大し た部位を示す。画像下にある color scale の数值は $\mathrm{t}$ 值（ $\mathrm{t}=2.242 ）$ を表す。

について，患者群の感覚運動領野，前頭前野および後 頭葉の広範な領域に $\mu$ 波, $\alpha$ 波の有意な発現を認めた。 これは従来発生源とされる感覚運動領野 ${ }^{13)}$, 前頭葉 ${ }^{25)}$ および後頭葉 ${ }^{26)}$ と一致する結果となり，また，本条件 のような安静時に認められる $\mu$ 波は, 感覚運動領野 における神経興奮の抑制を反映したもののみならず, $\alpha$ 波と同様に安静状態を反映したものと捉えることが できる ${ }^{27)}$ ため，本結果は，これまで報告されている安 静時における10 $13 \mathrm{~Hz}$ 周波数帯域での脳機能状態を 追認する結果となった。このことは同時に, 本研究で 計測した脳波データの信頼性を裏付けるものとも考え られた。
しかしながら，感覚運動領野や後頭葉に比較し前頭 前野での $\alpha$ 波に減少を認めたことに関して，一般に， $\alpha$ 波の発現量は年齢とともに減少 ${ }^{28)}$ ᄂ, 他の周波数帯 域成分との発現優勢率においても, 今回解析した High $\alpha$ 帯域成分は年齢とともに減少する ${ }^{28)}$ 。さらに, 脳血 管障害患者における脳波の特性として， $\alpha$ 波の左右差 は障害部位に限局せず，感覚運動領野や後頭葉にみら れることが多いとされ, 視床出血では視床前内側部の 障害で $\alpha$ 波が抑制される ${ }^{29)}$ 。本研究の対象者において は, 加齢に加え部位病巣が視床かつ前部, 内側部に呈 する者が多かったことから，前頭前野の $\alpha$ 波が他領 域に比較し減少していたのではないかと考えられた。 
振動刺激における $\mu$ 波周波数帯域での脳内神経活 動性について, 患者群の感覚運動領野には $\mu$ 波の発 現を認めなかった。これは, 筋紡錘からの運動感覚情 報処理や運動知覚において重要な脳領域30である感覚 運動領野への感覚運動情報が増加し, 感覚運動領野の 神経活動性に伴う両側 ${ }^{31}$ の神経細胞活動の非同期性に

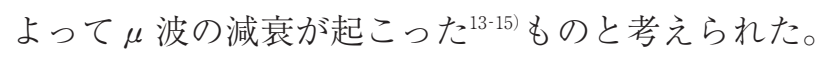
特に, 運動野 BA 4 の神経活動は, 単に筋紡錘からの 感覚情報処理にのみ関与しているのではなく, 処理の 結果生じる運動錯覚などの感覚運動情報そのものにも 関係しており ${ }^{30)}$, 運動錯覚の知覚量は運動野の興奮が 高いときほど大きい2)。これらのことから, 振動刺激 により惹起された運動錯覚が, 感覚運動領野の神経活 動性を高めることを示唆する結果となった。

より詳細に振動刺激がもたらす運動錯覚の影響を検 証するため, 振動刺激と安静における $\mu$ 波带域の脳 内神経活動を比較した結果, 安静は振動刺激に比べ, 感覚運動領野および補足運動野BA６において有意に 増加した。運動錯覚の知覚量そのものに関与する運動 野BA 4 のみでなく, 補足運動野 BA 6 の神経活動性 にも差を認めたことについて, 補足運動野BA 6 は, 感覚運動領野に対して情報の指向処理を行う ${ }^{32}$.33 領野 とされることから, 感覚運動野との間には密接な機能 的連関を持つことが考えられる。さらに, 実際の運動 時のみならず運動錯覚を起こしているときのような感 覚運動情報の空間認知処理過程に深く関与しており ${ }^{34)}$, 運動錯覚に必要な過去の感覚運動経験を運動イメージ としてシミュレートしたものを貯蔵し10), それら感覚 運動情報の識別35.36)を行う領域とされる。本研究では, 感覚運動領野と補足運動野BA 6 に対して, 時系列解 析を行っていないため神経活動の順序性については言 及できないが, これらの領域において, 実際の感覚運 動情報のみならず，運動実行への準備段階にあたる， いわゆる「アイドリング」リズム ${ }^{37}$ としての神経活動 をも反映した $\mu$ 波に減少がみられたことで, 今回の 脳波解析結果が, 振動刺激直後からの脳内神経情報処 理過程を包括した結果であったことを示唆するととも に, 運動錯覚においては運動イメージの関与が重要で ある可能性を示唆した。

本研究では, 脳血管障害後の脳機能状態を鋭敏に反 映する ${ }^{38}$ 有用なツールとしての脳波解析を用いて, 運 動錯覚が脳血管障害患者の脳内神経活動へどのような 影響を及ぼすかを，脳波 $\mu$ 波による脳機能イメージ ング解析により検討した。その結果，運動障害をもつ
脳血管障害患者においても運動錯覚が惹起され，感覚 運動領野, 補足運動野 BA 6 の神経活動性を高めるこ とが示唆された。このことから, 運動錯覚における運 動イメージの重要性が導かれたが, 本研究では, 感覚 運動領野, 補足運動野㧍よび関連領域の神経活動性を 電流密度として数值化し, 運動イメージ能力評価や運 動機能評価との比較検証を行っていない。今後は, 感 覚運動領野と関連領野の機能的連関を脳波解析により 詳細に検討することに加え, 感覚運動領野の神経活動 性と運動錯覚が惹起されるまでの生成時間や, 補足運 動野に扔けるイメージ想起能力を定量的に評価し健常 者と比較検討することが必要と思われる。

謝辞 : 本研究は JSPS 科研費25882038の助成を受けて 実施された研究の一部である。

\section{〈引用文献〉}

1) Goodwin GM. McCloskey DI, Matthews PBC: The contribution of muscle afferents to kinaesthesia shown by vibration induced illusions of movement and by the effects of paralysing joint afferents. Brain, 1972, 95(4): 705-48.

2 ) Naito E, Roland PE, Ehrsson HH: I Feel My Hand Moving: A New Role of the Primary Motor Cortex in Somatic Perception of Limb Movement. Neuron, 2002, 36(5): 979-88.

3 ) Ramachandran VS, Rogers-Ramachandran D, Cobb S : Touching the phantom limb. Nature, 2002, 377: 489-90.

4 ) Altschuler EL, Wisdom SB, Stone L, et al.: Rehabilitation of hemiparesis after stroke with a mirror. Lancet, 1999, 353 (9169): 2035-6.

5 ) Dohle C, MPhil MD: Mirror Therapy Promotes Recovery From Severe Hemiparesis: A Randomized Controlled Trial. Neurorehabil Neural Repair, 23(3): 209-17.

6 ) Hagura N. Takei T, Hirose S, et al.: Activity in the posterior parietal cortex mediates visual dominance over kinesthesia. J Neurosci, 2007, 27(26): 7047-53.

7 ) Bove M, Nardone A, Schieppati M: Effects of leg muscle tendon vibration on group Ia and group II reflex responses to stance perturbation in humans. J physiol, 2003, 550(2): 61730.

8 ) Naito E, Ehrsson HH, Geyer S, et al.: Illusory arm movements activate cortical motor areas: a positron emission tomography study. J Neurosci, 1999, 19(14): 6134-44.

9 ) Casini L. Romaiguère P, Ducorps A, et al:: Cortical correlates of illusory hand movement perception in humans: a MEG study. Brain Res, 2006, 1121(1): 200-6.

10) Harada T, Saito DN, Kashikura K, et al.: Asymmetrical neural substrates of tactile discrimination in humans: a functional magnetic resonance imaging study. J Neurosci, 2004, 24(34): 7524-30.

11) Gastauth H: Electrocorticographic study of the reactivity of 
rolandic rhythm. Rev Neurol (Paris), 1952, 87(2): 176-82.

12) Dornhege G, Benjamin B, Matthias K, et al.: Optimizing spatio-temporal filters for improving Brain-Computer Interfacing. Advances in Neural Inf. Proc. Systems, 2005, 18: 315-22.

13) Pfurtscheller G, Neuper C: Motor imagery activates primary sensorimotor area in humans. Neurosci Lett, 1997, 239(2-3): 65-8.

14) Muthukumaraswamy SD, Johnson BW, McNair NA: Mu rhythm modulation during observation of an objectdirected grasp. Brain Res Cogn Brain Res, 2004, 19(2): 195201.

15) Muthukumaraswamy SD, Johnson BW: Changes in rolandic mu rhythm during observation of a precision grip. Psychophysiology, 2004, 41(1): 152-6.

16) Evans N, Blanke O: Shared electrophysiology mechanisms of body ownership and motor imagery. Neuroimage, 2013, 64: 216-228.

17) Oldfield RC: The assessment and analysis of handedness: the Edinburgh inventory. Neuropsychologia, 1971, 9(1): 97113.

18) Naito E, Nakashima T, Kito T, et al. : Human limb-specific and non-limb-specific brain representations during kinesthetic illusory movements of the upper and lower extremities. Eur Neurosci, 2007, 25(11): 3476-87.

19）兒玉隆之, 中林紘二, 池田拓郎：腱振動刺激による運動錯 覚時の脳内神経活動の空間的解析-SLORETA 解析を用 いて -。臨床神経生理学, 2011，39(6)：505-12.

20) Burke D, Hagbarth KE, Löfstedt L, et al.: The responses of human muscle spindle endings to vibration during isometric contraction. J Physiol, 1976, 261(3): 695-711.

21) Pascual-Marqui RD. Michel CM, Lehmann D: Low Resolution Brain Electromagnetic Tomography: a new method for localizing electrical activity in the brain. Int. J.Psychophysiol, 1994, 18(1): 49-65.

22) Pascual-Marqui RD: Standardized low-resolution brain electromagnetic tomography (sLORETA): technical details. Methods Find Exp Clin Pharmacol, 2002, 24: 5-12.

23) Collins DL. Holmes CJ, Peters TK, et al: Automatic 3-D model-based neuroanatomical segmentation. Hum Brain Mapping, 1995, 3(3): 190-208.

24) Pascual-Marqui RD: arXiv:0711.1455

25) Laufs H, Kleinschmidt A, Beyerle A, et al.: EEG-correlated fMRI of human alpha activity. NeuroImage, 2003, 19(4): 1463-76.

26) Sadato N, Nakamura S, Oohashi T, et al.: Neural networks for generation and suppression of alpha rhythm: a PET study. Neuroreport, 1998, 9(5): 893-7.

27) Pfurtscheller G. Event-related synchronization (ERS): an electrophysiological correlate of cortical areas at rest. Electroencephalogr Clin Neurophysiol, 1992, 83(1): 62-9.

28) Nakano T, Miyasaka M, Ohtaka $T$, et al: Longitudinal changes in computerized EEG and mental function of the aged: a nine-year follow-up study. Int Psychogeriatr, 1992, 4
(1): 9-23.

29) Anderson P, Eccles JC: Inhibitory phasing of normal discharge. Nature. Lond, 1962, 196: 645-47.

30) Naito E: Sensing limb movements in the motor cortex: How humans sense limb movement. Neuroscientist, 2004, 10(1): 73-82.

31) Tanji J. Okano K, Sato KC: Neuronal activity in cortical motor areas related to ipsilateral, contralateral, and bilateral digit movements of the monkey. J Neurophysiol, 1988, 60(1): $325-42$.

32) Wiesendanger $\mathrm{R}$, Wiesendanger $\mathrm{M}$ : The thalamic connections with medial area 6 (supplementary motor cortex) in the monkey (macaca fascicularis). Exp Brain Res, 1985, 59 (1): $91-104$

33) Picard N, Strick PL: Activation of the supplementary motor area (SMA) during performance of visually guided movements. Cereb Cortex, 2003, 13(9): 977-86.

34) Boussaoud D: Attention versus intention in the primate premotor cortex. Neuroimage, 2001, 14(1 Pt 2): 40-5.

35) Van de Winckel A, Sunaert S, Wenderoth N, et al:: Passive somatosensory discrimination tasks in healthy volunteers: differential networks involved in familiar versus unfamiliar shape and length discrimination. Neuroimage, 2005, 26(2): 441-53.

36) Chung GH. Han YM, Jeong SH, et al.: Functional heterogeneity of the supplementary motor area. AJNR Am J Neuroradiol, 2005, 26(7): 1819-23.

37) Kuhlman WN: Functional topography of the human mu rhythm. Electroencephalogr Clin Neurophysiol, 1978, 44(1): 83-93.

38) Tecchio F, Zappasodi F, Pasqualetti, et al:: Rhythmic brain activity at rest from rolandic areas in acute monohemispheric stroke: a magnetoencephalographic study. Neuroimage, 2005, 28(1): 72-83. 